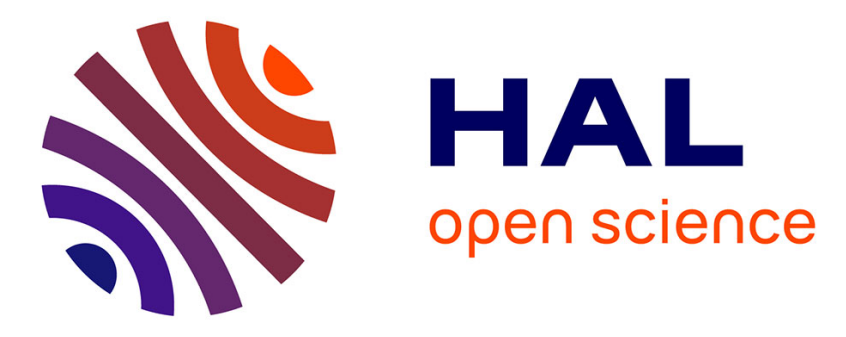

\title{
Hypoglutamatergic activity in the STOP knockout mouse: a potential model for chronic untreated schizophrenia.
}

Eiliv Brenner, Ursula Sonnewald, Annie Schweitzer, Annie Andrieux, Astrid Nehlig

\section{To cite this version:}

Eiliv Brenner, Ursula Sonnewald, Annie Schweitzer, Annie Andrieux, Astrid Nehlig. Hypoglutamatergic activity in the STOP knockout mouse: a potential model for chronic untreated schizophrenia.: 13C study of metabolism in STOP KO mice. Journal of Neuroscience Research, 2007, 85 (15), pp.3487-93. 10.1002/jnr.21200 . inserm-00379976

\section{HAL Id: inserm-00379976 https://www.hal.inserm.fr/inserm-00379976}

Submitted on 4 May 2009

HAL is a multi-disciplinary open access archive for the deposit and dissemination of scientific research documents, whether they are published or not. The documents may come from teaching and research institutions in France or abroad, or from public or private research centers.
L'archive ouverte pluridisciplinaire HAL, est destinée au dépôt et à la diffusion de documents scientifiques de niveau recherche, publiés ou non, émanant des établissements d'enseignement et de recherche français ou étrangers, des laboratoires publics ou privés. 


\section{Hypoglutamatergic activity in the STOP KO mouse: a potential model for chronic untreated schizophrenia}

Eiliv Brenner ${ }^{1}$, Ursula Sonnewald ${ }^{1}$, Annie Schweitzer ${ }^{2}$, Annie Andrieux ${ }^{2}$, Astrid Nehlig $^{3 *}$

1. Department of Neuroscience, Norwegian University of Science and Technology (NTNU), N-7489 Trondheim, Norway.

2. INSERM U 366, CEA-Grenoble, 38054 Grenoble, France

3. INSERM 666, University Louis Pasteur, 67085 Strasbourg, France

Address for correspondence: Astrid Nehlig, INSERM U 666, Faculty of Medicine, 11 rue Humann, 67085 Strasbourg Cedex, France, Tel: (33) 390.24.32.43, Fax: (33) 390.24.32.56

E-mail: nehlig@neurochem.u-strasbg.fr

Number of pages: 22

Number of words in text: 3171

Number of words in abstract: 200

Number of tables: 1

Number of figures: 4

Running title: ${ }^{13} \mathrm{C}$ study of metabolism in STOP KO mice

Key words: glutamate, glutamine, neurons, astrocytes, STOP KO mice, schizophrenia 


\begin{abstract}
In mice, the deletion of the STOP protein leads to hyperdopaminergia and major behavioral disorders that are alleviated by neuroleptics, hence representing a potential model of schizophrenia. The reduction of the glutamatergic synaptic vesicle pool in the hippocampus could reflect a disturbance in glutamatergic neurotransmission in this model. Here we examined potential disturbances in energy metabolism and interactions between neurons and glia in 15 week-old STOP KO, wild type and heterozygous mice. Animals received [1$\left.{ }^{13} \mathrm{C}\right]$ glucose and $\left[1,2-{ }^{13} \mathrm{C}\right]$ acetate, the preferential substrates of neurons and astrocytes, respectively. Extracts from the whole forebrain and midbrain were analyzed by HPLC, ${ }^{13} \mathrm{C}$ and ${ }^{1} \mathrm{H}$ NMR spectroscopy. Amounts and labeling of most metabolites were unchanged. However, glutamine concentration and amount of $\left[4,5-{ }^{13} \mathrm{C}\right]$ glutamine derived from $[1,2-$ ${ }^{13} \mathrm{C}$ ]acetate significantly decreased by $17 \%$ and $18 \%$, respectively, in STOP KO compared to wild type mice. The amount of $\left[4-{ }^{13} \mathrm{C}\right]$ glutamate was decreased in STOP KO and heterozygous compared to wild type mice. GABA labeling was not influenced by the genotype. Since STOP deficient mice have a lower synaptic vesicle density, less glutamate is released to the synaptic cleft leading to decreased stimulation of the postsynaptic glutamate receptors, reflecting increased glutamine metabolism only in the vicinity of the postsynapse of STOP KO mice.
\end{abstract}




\section{Introduction}

In the past twenty years, a neurodevelopmental origin for schizophrenia has become the prevailing pathogenic hypothesis for the disorder (Harrison, 1999; Marenco and Weinberger, 2000). Schizophrenia is regarded as a disease mainly expressed at the synapse level on the basis of both the hypothesis of a functional disconnection (Friston, 2002) and the data from genetic studies using DNA microarrays (Mirnics et al., 2001). For a long time, the "dopaminergic hypothesis" of schizophrenia based on the hyperactivity of the dopaminergic system was the prevailing hypothesis for the disease. Indeed, it is well known that amphetamine and cocaine that release or inhibit the reuptake of dopamine, respectively, induce psychosis (Seeman, 1987). However, a dysfunctioning of other neurotransmission systems has also been postulated and a more recent view includes disturbances also at the level of serotonin and glutamate neurotransmissions (Carlsson et al., 2001).

The "glutamatergic hypothesis" of schizophrenia comes from the observation that $\mathrm{N}$ methyl-D-aspartate (NMDA) glutamate-receptor antagonists, such as phencyclidine (Halberstadt, 1995) and ketamine (Lahti et al., 1995) have been shown to cause strong psychotomimetic effects with hallucinations and psychomotor signs. In contrast to dopaminergic agonists, which only mimic the positive symptoms of schizophrenia, NMDA antagonists produce the whole spectrum including negative and cognitive symptoms. The proposed mechanisms for a dysfunction of glutamatergic neurotransmission include interactions between the dopaminergic and glutamatergic systems (Carlsson et al., 2001), excitotoxic neuronal damage in hippocampus and cortex (Deutsch et al., 2001) and alterations in glutamine and glutamate metabolism (Brenner et al., 2005; Eyolfsson et al., 2006; Kondziella et al., 2005). It has been suggested that the dysregulation of dopamine transmission in schizophrenia may be secondary to alterations in glutamatergic NMDA receptor-mediated transmission (Carlsson et al., 2004; Olney and Farber, 1995). Indeed, in healthy volunteers receiving ketamine, the amplitude of amphetamine-induced dopamine release was significantly enhanced compared to control conditions (Kegeles et al., 2000). 
Thus, the elevated dopamine release seen in schizophrenic patients after amphetamine administration may well be secondary to a failure in glutamatergic control of dopamine neurons. This hypothesis is supported by experimental studies in rats (Miller and Abercrombie, 1996).

Glutamate is the most important excitatory neurotransmitter in the mammalian brain. In the basal state, $60-75 \%$ of the total cortical glucose utilization corresponds to glutamatergic neuron activity, $10-15 \%$ reflect GABAergic neurotransmission and $10-15 \%$ glial needs (Lebon et al., 2002; Shulman et al., 2004; Sibson et al., 2001). The synthesis of glutamate and GABA in neurons is closely connected to astrocytic metabolism and the homeostasis of glutamate is crucial to brain function for many reasons. Firstly, fast removal of glutamate from the synaptic cleft by astrocytes is necessary for short glutamate action on the postsynaptic target cell and thereby precise information signaling. Secondly, high extracellular concentration of glutamate is neurotoxic and excessive glutamate release may participate in the pathophysiology of many brain disorders, possibly involving schizophrenia (Deutsch et al., 2001). Thirdly, since neurons lack the main anaplerotic enzyme in the brain, pyruvate carboxylase (Shank et al., 1985), they depend on astrocytic supply of tricarboxylic acid (TCA) cycle intermediates because the constant loss of amino acid neurotransmitters from neurons would otherwise lead to restriction of neurotransmitter precursors (Sonnewald et al., 1993). After being released from neurons, glutamate is cleared from the synapses by astrocytes, which transform glutamate to glutamine via glutamine synthetase which is an astrocyte specific enzyme (Norenberg and Martinez-Hernandez, 1979). Astrocytes release glutamine into the extracellular space, from where it is taken up by neurons and converted back to glutamate and GABA or enters the TCA cycle via 2-oxoglutarate to provide carbon skeletons for the synthesis of other metabolites. This shuttling between astrocytes and neurons is called the "glutamine-glutamate cycle" (Berl and Clark, 1983).

An excellent tool to study metabolic pathways and glial-neuronal metabolic interactions is ${ }^{13} \mathrm{C}$ nuclear magnetic resonance spectroscopy (NMRS) (see Sonnewald and Kondziella, 
2003 for review). The simultaneous injection of $\left[1,2-{ }^{13} \mathrm{C}\right]$ acetate and $\left[1-{ }^{13} \mathrm{C}\right]$ glucose allows to study astrocytic and neuronal metabolism in the same animal (Taylor et al., 1996). In the present work, this technique was applied to the characterization of neuronal and astrocytic metabolism in STOP (Stable Tubule only Polypeptide) protein knockout (KO) mice which have been proposed to be a "meaningful model for the study of the pathophysiology of schizophrenia" (Brun et al., 2005). The STOP protein is a protein involved in the cold stability of microtubules, synaptic plasticity and neurotransmission (Andrieux et al., 2002). The deletion of the STOP protein leads to a decrease in synaptic vesicle density in hippocampal CA1 terminals, impaired long term potentiation and depression at the level of Schaffer collaterals-CA1 pyramidal cell synapses. STOP KO mice are also characterized by disorganized activity with frequent shifts between hyperlocomotion and prostration, anxietyrelated behavior, inability to perform object recognition tasks and social withdrawal (Andrieux et al., 2002). These mice also exhibit increased dopaminergic neurotransmission and increased efflux of dopamine in the nucleus accumbens upon stimulation (Brun et al., 2005). Taken together, these studies indicate the association between limbic hyper-dopaminergy and hippocampal hypo-glutamatergy in these mice (Andrieux et al., 2002; Brun et al., 2005). To study the cerebral metabolism of glutamate further, we explored the metabolic fate of [1$\left.{ }^{13} \mathrm{C}\right]$ glucose and $\left[1,2-{ }^{13} \mathrm{C}\right]$ acetate using ${ }^{13} \mathrm{C}$ and ${ }^{1} \mathrm{H}$ NMRS, and HPLC in the brain of wild type (WT), heterozygous and STOP KO mice. Acetate and glucose are both precursors for acetylCoA which enters the TCA cycle. Whereas acetyl-CoA from glucose is metabolized more in the neuronal TCA cycle (Qu et al., 2000), acetate is metabolized predominantly in astrocytes since it is selectively taken up into these cells (Waniewski and Martin, 1998).

\section{Materials and Methods}

STOP KO male mice (STOP-/-), heterozygous (STOP+/-) and control WT littermates (STOP+/+), 15 week-old, were generated as previously described (Andrieux et al., 2002). Mice were housed eight per cage and maintained in quiet, uncrowded facilities (room temperature of $22^{\circ} \mathrm{C} \pm 1^{\circ} \mathrm{C}$ ) on a 12 hour light-dark schedule (7:00 a.m., lights on), humidity 
$60 \%$, and given unlimited access to lab chow and water. Males only were used for these experiments to eliminate confounding effects of variable estrogen level on neuronal excitability (Murphy et al., 1998). All animal experimentation was performed in accordance with the rules of the European Committee Council Direction of November 24, 1986 (86/69/EEC) and the French Department of Agriculture (Licence $\left.N^{\circ} 67-97\right)$. The animals (10 in each group) were injected intraperitoneally with $\left[1-{ }^{13} \mathrm{C}\right]$ glucose $(543 \mathrm{mg} / \mathrm{kg}, 0.3 \mathrm{M}$ solution) and $\left[1,2-{ }^{13} \mathrm{C}\right]$ acetate $(504 \mathrm{mg} / \mathrm{kg}, 0.6 \mathrm{M}$ solution) followed by decapitation twenty minutes later. The heads were immediately frozen in liquid nitrogen and stored at $-80^{\circ} \mathrm{C}$. Brains were removed from the slightly thawed skull, and because of their small size and limitations of sensitivity of the method, the forebrain/midbrain (cerebrum) including cerebral cortex and subcortical regions was used. The brainstem and cerebellum were discarded. The tissue was homogenized in $7 \%(\mathrm{w} / \mathrm{v})$ perchloric acid and centrifuged at 4,000 $\mathrm{g}$ for $5 \mathrm{~min}$. The procedure was repeated, the supernatants pooled and neutralized with $1 \mathrm{M} \mathrm{KOH}$ followed by lyophilization.

High Pressure Liquid Chromatography (HPLC)

Amino acids in cell extracts and medium were quantified by HPLC on a Hewlett Packard 1100 system (Agilent Technologies, Palo Alto, CA, USA). The amino acids were pre-column derivatized with o-phthaldialdehyde (Geddes and Wood, 1984) and subsequently separated on a ZORBAX SB-C18 $(4.6 \times 250 \mathrm{~mm}, 5 \mu \mathrm{m})$ column from Agilent using a phosphate buffer $(50 \mathrm{mM}, \mathrm{pH}=5.9)$ and a solution of methanol $(98.75 \%)$ and tetrahydrofurane $(1.25 \%)$ as eluents. The separated amino acids were detected with fluorescence and quantified by comparison to a standard curve derived from standard solutions of amino acids run after every twelve samples.

\footnotetext{
${ }^{13}$ C NMR spectroscopy
} 
Proton decoupled $125.77 \mathrm{MHz}{ }^{13} \mathrm{C}$ NMR spectra were obtained using a Bruker DRX-500 spectrometer after the samples had been re-dissolved in $300 \mu \mathrm{L} \mathrm{D}_{2} \mathrm{O}$ containing ethylene glycol $0.1 \%$ as an internal standard. Scans were accumulated with a $30^{\circ}$ pulse angle and 25 $\mathrm{kHz}$ spectral width with $64 \mathrm{~K}$ data points. The number of scans was 9000 . The acquisition time was $1.308 \mathrm{~s}$, the relaxation delay $0.5 \mathrm{~s}$.

\section{${ }^{1}$ H NMR spectroscopy}

A DRX-500 spectrometer was used to obtain ${ }^{1} \mathrm{H}$ NMR spectra with a sweep width of $8 \mathrm{kHz}$ with $32 \mathrm{~K}$ data points. The pulse angle was $90^{\circ}$, the acquisition time $2.045 \mathrm{~s}$ and the relaxation delay was $10 \mathrm{~s}$. The number of scans was 250 . Water suppression was set the residual $\mathrm{H}_{2} \mathrm{O}$ resonance.

\section{Labeling patterns}

Most of the singlet peaks in the NMR spectrum (Figure 1) represent label from [1$\left.{ }^{13} \mathrm{C}\right]$ glucose. In contrast, the doublets seen in the spectrum are mostly derived from [1,2${ }^{13} \mathrm{C}$ ]acetate and thus astrocytic metabolism (Waniewski and Martin, 1998). [1- $\left.{ }^{13} \mathrm{C}\right]$ glucose is converted to pyruvate via glycolysis and can form $\left[3-{ }^{13} \mathrm{C}\right]$ alanine and $\left[3-{ }^{13} \mathrm{C}\right]$ lactate. Pyruvate may enter the TCA cycle via $\left[2-{ }^{13} \mathrm{C}\right.$ ]acetyl-CoA, which will lead to the formation of [4$\left.{ }^{13} \mathrm{C}\right]$ glutamate and glutamine or $\left[2-{ }^{13} \mathrm{C}\right] \mathrm{GABA}$. If the ${ }^{13} \mathrm{C}$ label stays for a second turn in the TCA cycle the $\left[2-{ }^{13} \mathrm{C}\right]$ or $\left[3-{ }^{13} \mathrm{C}\right]$ positions of glutamate and glutamine or the $\left[3-{ }^{13} \mathrm{C}\right]$ or $\left[4-{ }^{13} \mathrm{C}\right]$ positions of GABA can be labeled. Alternatively, in astrocytes, pyruvate can be carboxylated by pyruvate carboxylase $(P C)$ to oxalacetate, which can lead to the synthesis of [2$\left.{ }^{13} \mathrm{C}\right]$ glutamate and glutamine or $\left[4-{ }^{13} \mathrm{C}\right] \mathrm{GABA}$. $\left[1,2-{ }^{13} \mathrm{C}\right]$ Acetate can also be converted to acetyl-CoA, however, the product, $\left[1,2-{ }^{13} \mathrm{C}\right]$ acetyl-CoA, will have two ${ }^{13} \mathrm{C}$ atoms resulting in doublet formation. Thus, $\left[4,5-{ }^{13} \mathrm{C}\right]$ glutamate and glutamine or $\left[1,2-{ }^{13} \mathrm{C}\right] \mathrm{GABA}$ are formed (Figure 2). After the second turn of the TCA cycle this label will be in the $\left[1,2-{ }^{13} \mathrm{C}\right]$ or $\left[3-{ }^{13} \mathrm{C}\right]$ 
positions of glutamate and glutamine and the $\left[2-{ }^{13} \mathrm{C}\right]$ or $\left[3-{ }^{13} \mathrm{C}\right]$ positions of GABA. Glutamine is labeled more from $\left[1,2-{ }^{13} \mathrm{C}\right]$ acetate (doublet) than from $\left[1-{ }^{13} \mathrm{C}\right]$ glucose (singlet); the opposite is the case for glutamate and GABA. Alanine, lactate, N-acetylaspartate (NAA) in the C-6 position and succinate are mainly labeled from glucose. Creatine, taurine and the aspartate group in $\mathrm{N}$-acetylaspartate are not labeled during the 20 min period of the present experiment; the naturally abundant ${ }^{13} \mathrm{C}$ gives rise to the observed singlets in Figure 1 . Since both acetyl-CoA and oxalacetate can be labeled or unlabeled, the number of possible isotopomers of the TCA cycle derived metabolites is large and only compounds derived from the first and the second turns are presented in Figure 2. Metabolic ratios were calculated but no differences were detected between groups (for details see Melø et al., 2006; Brenner et al., 2005).

\section{Data analysis}

The amounts of ${ }^{13} \mathrm{C}$ in the different metabolites were quantified from integrals of the relevant peaks obtained from NMR spectra with ethylene glycol as an internal standard. Factors for nuclear Overhauser and relaxation effects were applied to all spectra. Amounts of metabolites were quantified either from ${ }^{1} \mathrm{H}$ NMR spectra using ethylene glycol as internal standard and correcting for number of protons or by HPLC.

All results are given as means \pm standard deviation. Statistics were performed using the two-tailed, unpaired Student's t-test; $p<0.05$ was considered significant.

\section{Results}

In the three genotypes, brain levels of all amino acids related to the TCA cycle and taurine, glutathione, succinate, lactate and $\mathrm{NAD}^{+}$were similar. The only difference was a significant $(17 \%)$ decrease in the cerebral concentration of glutamine of STOP KO compared to WT mice (Table 1). 
Injection of $\left[1-{ }^{13} \mathrm{C}\right]$ glucose and $\left[1,2-{ }^{13} \mathrm{C}\right]$ acetate lead to efficient labeling of many metabolites (Figure 1). Particularly, labeling of glutamate and glutamine C-3 and C-4, GABA C-2 and C-3, aspartate and lactate C-3 are shown in Figure 1. Labeling patterns from [1$\left.{ }^{13} \mathrm{C}\right]$ glucose and $\left[1,2-{ }^{13} \mathrm{C}\right]$ acetate from the first and second turns of the TCA cycle are shown in Figure 2. The amount of $\left[4,5-{ }^{13} \mathrm{C}\right]$ glutamine, derived from $\left[1,2-{ }^{13} \mathrm{C}\right]$ acetate, was significantly decreased by $18 \%$ in STOP KO compared to WT mice (Figure 3 ). The amount of [4,5$\left.{ }^{13} \mathrm{C}\right]$ glutamate tended to be decreased in STOP+/- and STOP-/- mice compared to control animals but the difference was not significant. Levels of $\left[1,2-{ }^{13} \mathrm{C}\right] \mathrm{GABA}$ were similar in the three genotypes. Label from $\left[1-{ }^{13} \mathrm{C}\right]$ glucose in the form of $\left[4-{ }^{13} \mathrm{C}\right] \mathrm{glutamate}$ and $[4-$ ${ }^{13}$ C]aspartate was decreased by $16 \%$ and $21 \%$ respectively in KO STOP compared to wild type mice while the labeling of $\left[2-{ }^{13} \mathrm{C}\right] \mathrm{GABA}$ and $\left[4-{ }^{13} \mathrm{C}\right] \mathrm{GABA}$ did not depend on the genotype. The pyruvate carboxylase/dehydrogenase (PC/PDH) ratios were calculated and no significant differences between the groups were detected (data not shown). Generally, carboxylation was low in all groups.

\section{Discussion}

The cytosolic step of neuronal glutamate and astrocytic glutamine metabolism were affected in the STOP KO mouse, whereas mitochondrial metabolism appeared unchanged. We propose that glutamine metabolism is decreased in major parts of the astrocytes of STOP $\mathrm{KO}$ mice, but unaltered in areas close to the presynapse and decreased in the vicinity of the postsynapse.

The STOP protein is a protein involved in the cold stability of microtubules, synaptic plasticity and neurotransmission (Andrieux et al., 2002). Different isoforms of the STOP protein are expressed in neurons and astrocytes (Galiano et al., 2004) and it has been shown that in knockout mouse embryos, microtubule cold stability was lost in both neurons and glial cells while being partly preserved in heterozygous mice (Andrieux et al., 2002). This mouse model was used in the present study and a decreased level of glutamine was found in 
the cerebrum of homozygous KO compared to WT mice. The glutamine level in heterozygous mice was not significantly different from both wild type and knockout mice, indicating that reduced amounts of the STOP protein are sufficient for maintaining glutamine synthesis. As in STOP deficient mice, reduced amounts of glutamine were found in the left anterior cingulate cortex of patients with chronic schizophrenia in addition to reduction in glutamate (Theberge et al., 2003). This decrease of glutamate and glutamine could possibly be an effect of long term treatment with neuroleptics, but the authors argue that this is unlikely and the present study supports this view. Two ${ }^{1} \mathrm{H}$ NMR spectroscopy studies of patients with never treated first episode schizophrenia, showed increased levels of glutamine in the medial prefrontal cortex and the left anterior cingulate cortex and thalamus, respectively (Bartha et al., 1997; Theberge et al., 2002). Taken together, these reports indicate that first episode schizophrenic patients have an increased glutamine level in specific areas of the brain, whereas chronic patients have decreased levels of glutamate and glutamine. Thus, it appears that the 15-week-old STOP KO mice mimic chronic schizophrenia but not first episode schizophrenia, and hence STOP KO mice might be a good model for chronic schizophrenia.

In the present study, a significant decrease was found in the amount of $[4,5$ $\left.{ }^{13} \mathrm{C}\right]$ glutamine which is derived from $\left[1,2-{ }^{13} \mathrm{C}\right]$ acetate and therefore from astrocytic metabolism, indicating decreased glutamine synthesis in the STOP KO mice. A similar decrease was observed in the rat model of schizophrenia induced by the chronic injection of MK801 (Kondziella et al., 2005). Pyruvate carboxylation, another astrocyte specific pathway, was not changed compared to WT or heterozygous mice. It is conceivable that changes in microtubule stability will affect cytosolic enzymes such as glutamine synthetase (GS), whereas pyruvate carboxylase (PC), located on/in mitochondria was not affected. Other cytosolic enzymes, those related to glycolysis appeared unaffected, since the amounts of lactate and alanine were unchanged. The osmolyte taurine, the antioxidant glutathione and energy metabolism related $\mathrm{NAD}^{+}$were unchanged as well. As stated in the introduction, the astrocytes supply neurons with glutamine which can be converted to glutamate by the 
mitochondrial enzyme phosphate activated glutaminase (PAG). It is also important to note in this context that most of the glutamate in brain is located in glutamatergic neurons (Ottersen and Storm Mathisen 1986). Since the amount of $\left[4,5-{ }^{13} \mathrm{C}\right]$ glutamine was decreased in the present study in STOP KO compared to WT mice, a decreased level of $\left[4,5-{ }^{13} \mathrm{C}\right]$ glutamate would be expected, since the latter is directly derived from $\left[4,5-{ }^{13} \mathrm{C}\right]$ glutamine via PAG. However, no decrease was observed. The amount of $\left[4,5-{ }^{13} \mathrm{C}\right]$ glutamate in STOP KO animals was at the control level. This could be due to decreased catabolism of [4,5$\left.{ }^{13} \mathrm{C}\right]$ glutamate, increased PAG activity or normal release of $\left[4,5-{ }^{13} \mathrm{C}\right]$ glutamine, despite lower intracellular amounts. The fact that also $\left[1,2-{ }^{13} \mathrm{C}\right] \mathrm{GABA}$, another neuronal metabolite derived from $\left[4,5-{ }^{13} \mathrm{C}\right]$ glutamine, was unchanged, indicates that the latter situation is most likely occurring.

The labeling (data not shown) and concentrations of the metabolites associated with primarily neuronal mitochondria, such as $\mathrm{N}$-acetylaspartate, succinate and aspartate (Baslow, 2003; Palaiologos et al., 1988; Sonnewald et al., 1996) were similar in STOP KO, heterozygous and WT mice. A decrease was found in glutamate labeled from $\left[1-{ }^{13} \mathrm{C}\right]$ glucose, i.e. $\left[4-{ }^{13} \mathrm{C}\right]$ glutamate which is derived from neuronal metabolism, in the STOP KO mice compared to WT. A decrease in $\left[4-{ }^{13} \mathrm{C}\right]$ glutamate concentration was also observed in the chronic MK801 rat model of schizophrenia (Kondziella et al., 2005). Levels of $\left[2-{ }^{13} \mathrm{C}\right] \mathrm{GABA}$ were unchanged in the STOP KO mice but decreased in MK801-treated rats. The decrease in $\left[4-{ }^{13} \mathrm{C}\right]$ glutamate in the STOP KO mice could indicate that the cytosolic glutamate synthesis from 2-oxoglutarate was impaired as a result of microtubule instability. Glutamate in neurons (mostly $\left[4-{ }^{13} \mathrm{C}\right]$ glutamate) is accumulated into vesicles and released. As mentioned above, this glutamate can be converted to $\left[4-{ }^{13} \mathrm{C}\right]$ glutamine in the astrocytes for future transport to neurons. However, in spite of a reduction in the amount of [4$\left.{ }^{13} \mathrm{C}\right]$ glutamate, no change was detected in $\left[4-{ }^{13} \mathrm{C}\right]$ glutamine concentration. This could possibly reflect increased GS activity, which is inconsistent with the decrease in GS activity that we postulated above in the light of decreased labeling of $\left[4,5-{ }^{13} \mathrm{C}\right] \mathrm{glutamine}$. However, the cerebral metabolism of glutamate in astrocytes is compartmentalized and there have to 
be domains, which release glutamine, that is taken up by the neuronal cell body (Figure 4). We postulate that GS activity is decreased in regions of the astrocyte that are close to the non-synaptic parts of neurons (Figure 4 [1]), leading to decreased amounts of [4$\left.{ }^{13} \mathrm{C}\right]$ glutamine. However, in the synaptic region other mechanisms apply (Figure $4[3,4,5]$ ). Glutamate is released from vesicles docking the presynaptic membrane. Previous reports have shown that STOP KO mice have a lower synaptic vesicle density (Andrieux et al., 2002). This indicates that less glutamate is released to the synaptic cleft leading to decreased stimulation of the postsynaptic glutamate receptors. Upon depolarization, the activation of NMDA receptors by glutamate allows $\mathrm{Ca}^{2+}$ influx through the ion channel. $\mathrm{Ca}^{2+}$ entry into the postsynaptic neuron activates nitric oxide synthase (NOS) through a second messenger pathway involving calmodulin (Kosenko et al., 2003). Nitric oxide (NO) synthesized in the postsynaptic neuron does not only affect the post- and presynaptic neuron but also the nearby astrocyte resulting in tonic inhibition of GS (Kosenko et al., 2003). Reduced presynaptic glutamate release would then, through disinhibition of the astrocytic GS, cause increased glutamine production in the astrocyte (Figure $4[3,4,5]$ ). Indeed the unchanged amount of $\left[4-{ }^{13} \mathrm{C}\right]$ glutamine in the presence of decreased $\left[4-{ }^{13} \mathrm{C}\right]$ glutamate could support this hypothesis. Modification of GS activity due to changes in NMDA receptor stimulation has been reported previously by Brenner et al. (2005). In that study, rats received a single injection of the NMDA receptor antagonist MK-801, a model for schizophrenia; increased GS activity was postulated in astrocyte processes close to the postsynaptic neuron (Brenner et al., 2005).

In conclusion, the results of the present study support previous indications that STOP KO mice have reduced synaptic glutamate release and are in a hypoglutamatergic state. Hypoglutamatergia is thought to be an important causal mechanism of schizophrenia. STOP KO mice also show signs of hyperdopaminergia (Brun et al., 2005). This, together with the reduction in glutamine levels, makes the STOP KO mouse a valid model of chronic schizophrenia and supports the hypothesis that dysregulation of dopamine in schizophrenia 
coexists with and may be secondary to alterations in glutamatergic NMDA receptor-mediated transmission (Carlsson et al., 2004; Olney and Farber, 1995).

\section{Acknowledgements}

The excellent technical assistance of Bich-Thuy Pham-Lê and Bente Urfjell is greatly acknowledged. 


\section{References}

Andrieux A., Salin P. A., Vernet M. et al (2002) The suppression of brain cold-stable microtubules in mice induces synaptic defects associated with neuroleptic-sensitive behavioral disorders. Genes Dev. 16, 2350-2364.

Bartha R., al-Semaan Y. M., Williamson P. C. et al (1999) A short echo proton magnetic resonance spectroscopy study of the left mesial-temporal lobe in first-onset schizophrenic patients. Biol. Psychiatry. 45, 1403-1411.

Baslow M. H. (2003) Brain N-acetylaspartate as a molecular water pump and its role in the etiology of Canavan disease: a mechanistic explanation. J. Mol. Neurosci. 21, 185-90.

Berl S. and Clarke D. D. (1983) The metabolic compartmentation concept, in Glutamine, Glutamate and GABA in The Central Nervous System, (Hertz L.; Kvamme E.; McGeer E. G. and Schousboe A., eds), pp. 205-217. Alan R. Liss, New York.

Brenner E., Kondziella D., Haberg A. and Sonnewald U. (2005) Impaired glutamine metabolism in NMDA receptor hypofunction induced by MK801. J. Neurochem. 94, 1594-1603.

Brun P., Bégou M., Andrieux A. et al (2005) Dopaminergic transmission in STOP null mice. J. Neurochem. 94, 63-73.

Carlsson M., Carlsson A. and Nilsson M. (2004) Schizophrenia: from dopamine to glutamate and back. Curr. Med. Chem. 11, 267-277.

Carlsson A., Waters N., Holm-Waters S. et al (2001) Interactions between monoamines, glutamate, and GABA in schizophrenia: new evidence. Annu. Rev. Pharmacol. Toxicol. 41, 237-260.

Deutsch S. I., Rosse R. B., Schwartz B. L. and Mastropaolo J. (2001) A revised excitotoxic hypothesis of schizophrenia: therapeutic implications. Clin. Neuropharmacol. 24, 43-49.

Eyjolfsson E. M., Brenner E., Kondziella D. and Sonnewald U. (2006) Repeated injection of MK801: An animal model of schizophrenia? Neurochem. Int. 48, 541-546.

Friston K. J. (2002) Dysfunctional connectivity in schizophrenia. World Psychiat. 1, 66-71.

Galiano M. R., Bosc C., Schweitzer A. et al (2004) Astrocytes and oligodendrocytes express different STOP protein isoforms. J. Neurosci. Res. 78, 329-337.

Geddes J. W. and Wood J. D. (1984) Changes in the amino acid content of nerve endings (synaptosomes) induced by drugs that alter the metabolism of glutamate and gammaaminobutyric acid. J. Neurochem. 42, 16-24.

Halberstadt A. (1995) The phencyclidine-glutamate model of schizophrenia. Clin. Neuropharmacol. 18, 237-249.

Harrison P. J. (1999) The neuropathology of schizophrenia. A critical review of the data and their interpretation. Brain 122, 593-624.

Kegeles L. S., Abi-Dargham A., Zea-Ponce Y. et al (2000) Modulation of amphetamineinduced striatal dopamine release by ketamine in humans: implications for schizophrenia. Biol. Psychiatry 48, 627-640.

Kondziella D., Brenner E., Eyjolfsson E. M. et al (2005) Glial-neuronal interactions are impaired in the schizophrenia model of repeated MK801 exposure. Neuropsychopharmacology [e-pub].

Kosenko E., Llansola M., Montoliu C. et al (2003) Glutamine synthetase activity and glutamine content in brain: modulation by NMDA receptors and nitric oxide. Neurochem. Int. 43:493-499.

Lahti A. C., Koffel B., LaPorte D. and Tamminga C. A. (1995) Subanesthetic doses of ketamine stimulate psychosis in schizophrenia. Neuropsychopharmacology 13, 9-19.

Lebon V., Petersen K. F., Cline G. W. et al (2002) Astroglial contribution to brain energy metabolism in humans revealed by ${ }^{13} \mathrm{C}$ nuclear magnetic resonance spectroscopy. Elucidation of the dominant pathway for neurotransmitter glutamate repletion and measurement of astrocytic oxidative metabolism. J. Neurosci. 22, 1523-1531. 
Marenco S. and Weinberger D. R. (2000) The neurodevelopmental hypothesis of schizophrenia: following a trail of evidence from cradle to grave. Dev. Psychopathol. 12, 501-527.

Melo T. M., Nehlig A. and Sonnewald U. (2006) Neuronal-glial interactions in rats fed a ketogenic diet. Neurochem. Int. 48, 498-507.

Miller D. W. and Abercrombie E. D. (1996) Effects of MK-801 on spontaneous and amphetamine-stimulated dopamine release in striatum measured with in vivo microdialysis in awake rats. Brain Res. Bull. 40, 57-62.

Mirnics K., Middleton F. A., Lewis D. A. and Levitt P. (2001) Analysis of complex brain disorders with gene expression microarrays: schizophrenia as a disease of the synapse. Trends Neurosci. 24, 479-486.

Murphy D. D., Cole N. B., Greenberger V. and Segal M. (1998) Estradiol increases dendritic spine density by reducing GABA neurotransmission in hippocampal neurons. $J$. Neurosci. 18, 2550-2559.

Norenberg M. D. and Martinez-Hernandez A. (1979) Fine structural localization of glutamine synthetase in astrocytes of rat brain. Brain Res. 161, 303-310.

Olney J. W. and Farber N. B. (1995) Glutamate receptor dysfunction and schizophrenia. Arch. Gen. Psychiatry 52, 998-1007.

Ottersen O.P. and Storm-Mathisen J. (1986) Excitatory amino acid pathways in the brain. Adv. Exp. Med. Biol. 203, 263-84.

Palaiologos G., Schousboe A. and Hertz L. (1988) Evidence that aspartate aminotransferase activity and ketodicarboxylate carrier function are essential for biosynthesis of transmitter glutamate. J. Neurochem. 51, 317-20.

Qu H., Haberg A., Haraldseth O. et al (2000) ${ }^{13} \mathrm{C}$ MR spectroscopy study of lactate as substrate for rat brain. Dev. Neurosci. 22, 429-436

Seeman P. (1987) Dopamine receptors and the dopamine hypothesis of schizophrenia. Synapse 1, 133-152.

Shank R. P., Bennett G. S., Freytag S. O. and Campbell G.L (1985) Pyruvate carboxylase: an astrocyte-specific enzyme implicated in the replenishment of amino acids neurotransmitter pool. Brain Res. 329, 362-367.

Shulman R. G., Rothman D. L., Behar K. L. and Hyder F. (2004) Energetic basis of brain activity: implications fro brain neuroimaging. Trends Neurosci. 27, 489-495.

Sibson N. R., Mason G. F., Shen J. et al (2001) In vivo ${ }^{13} \mathrm{C}$ NMR measurement of neurotransmitter glutamate cycling, anaplerosis and TCA cycle flux in rat brain during [2${ }^{13}$ C]glucose infusion. J. Neurochem. 76, 975-989.

Sonnewald U. and Kondziella D. (2003) Neuronal glial interaction in different neurological diseases studied by ex vivo ${ }^{13} \mathrm{C}$ NMR spectroscopy. NMR Biomed. 16, 424-429.

Sonnewald U., Therrien G. and Butterworth R. F. (1996) Portacaval anastomosis results in altered neuron--astrocytic metabolic trafficking of amino acids: evidence from ${ }^{13} \mathrm{C}-\mathrm{NMR}$ studies. J. Neurochem. 67, 1711-1717.

Sonnewald U., Westergaard N., Schousboe A. et al (1993) Direct demonstration by $\left[{ }^{13} \mathrm{C}\right]$ NMR spectroscopy that glutamine from astrocytes is a precursor for GABA synthesis in neurons. Neurochem. Int. 22, 19-29.

Theberge J., Al-Semaan Y., Williamson P. C. et al (2003) Glutamate and glutamine in the anterior cingulate and thalamus of medicated patients with chronic schizophrenia and healthy comparison subjects measured with 4.0-T proton MRS. Am. J. Psychiatry 160, 2231-2233.

Theberge J., Bartha R., Drost D. J. et al (2002) Glutamate and glutamine measured with 4.0 T proton MRS in never-treated patients with schizophrenia and healthy volunteers. Am. J. Psychiatry 159, 1944-1946.

Waniewski R. A. and Martin D. L. (1998) Preferential utilization of acetate by astrocytes is attributable to transport. J. Neurosci. 18, 5225-5233 


\section{Legends of figures}

Figure 1: ${ }^{13} \mathrm{C}$ NMR spectrum of cerebrum extract from STOP KO mice injected with [1,2$\left.{ }^{13} \mathrm{C}\right]$ acetate and $\left[1-{ }^{13} \mathrm{C}\right]$ glucose. Peak assignments; 1: glutamate C-2; 2: glutamine C-2; 3: aspartate C-2; 4: aspartate C-3; 5: GABA C-2; 6: succinate C-2/C-3; 7: glutamate C-4; 8: glutamine C-4; 9: glutamate C-3; 10: glutamine C-3; 11: GABA C-3; 12: N-acetylaspartate C3; 13: lactate C-3; 14: alanine C-3. The singlets are mostly derived from $\left[1-{ }^{13} \mathrm{C}\right]$ glucose and the doublets in the spectrum from $\left[1,2-{ }^{13} \mathrm{C}\right]$ acetate.

Figure 2: Schematic representation of ${ }^{13} \mathrm{C}$ labeling of glutamate, glutamine, GABA and aspartate originating from $\left[1-{ }^{13} \mathrm{C}\right]$ glucose $(\mathrm{a})$ or $\left[1,2-{ }^{13} \mathrm{C}\right]$ acetate $(\mathrm{b})$. Filled circles represent ${ }^{13} \mathrm{C}$ and empty circles ${ }^{12} \mathrm{C}$. TCA, tricarboxylic acid cycle; Glu, glutamate; Gln, glutamine.

Figure 3: Amount of ${ }^{13} \mathrm{C}$ labeled metabolites (nmol/g tissue) derived from $\left[1-{ }^{13} \mathrm{C}\right] \mathrm{glucose}$ (figure a) and $\left[1,2-{ }^{13} \mathrm{C}\right]$ acetate (figure b). Data represent means \pm S.D. of 10 mice in each group. ${ }^{*} p<0.05$, statistically significant difference from wild type mice.

Figure 4: Schematic representation of the glutamate-glutamine cycle related interactions of an astrocyte with a pre- and postsynaptic neuron. (1) $\left[1,2-{ }^{13} \mathrm{C}\right]$ Acetate is taken up by astrocytes, but not by neurons. Through the tricarboxylic cycle (TCA), $\left[1,2-{ }^{13} \mathrm{C}\right]$ acetatyl CoA is converted to $\left[4,5-{ }^{13} \mathrm{C}\right]$ glutamate. Glutamine synthetase (GS) converts $\left[4,5-{ }^{13} \mathrm{C}\right]$ glutamate to $\left[4,5-{ }^{13} \mathrm{C}\right]$ glutamine. We postulate that the STOP KO mice have a decreased GS activity in this non-synaptic region of the astrocyte. (2) Glucose is mostly taken up by neurons. $\left[1-{ }^{13} \mathrm{C}\right]$ glucose is after several steps converted to $\left[4-{ }^{13} \mathrm{C}\right]$ glutamate. In the STOP KO mice neuronal cytosolic glutamate synthesis is decreased. (3) Microtubule instability in the STOP KO mice probably leads to reduced synaptic glutamate release. (4) NMDA receptors are activated by synaptic glutamate and allow influx of $\mathrm{Ca}^{2+}$ into the postsynaptic dendrite. $\mathrm{Ca}^{2+}$ activates the enzyme nitric oxide synthase (NOS). (5) NO may diffuse into the astrocyte 
where it normally inhibits GS. In the STOP KO mice, reduced activation of NMDA receptors by glutamate leads to reduced NO production resulting in less inhibition of GS. This will only be the case in the part of the astrocyte close to the synapse. Abbreviations: $4,5-\mathrm{Gln}$, [4,5-13C]glutamine; 4,5-Glu, $\quad\left[4,5-1^{3} \mathrm{C}\right]$ glutamate; 4 -Gln, $\quad\left[4-{ }^{13} \mathrm{C}\right] g$ lutamine; $4-G l u$, $\left[4-{ }^{13}\right.$ C]glutamate; GS, glutamine synthetase; NO, nitric oxide; NOS, nitric oxide synthase; Pyr, pyruvate; TCA, tricarboxylic acid cycle. 


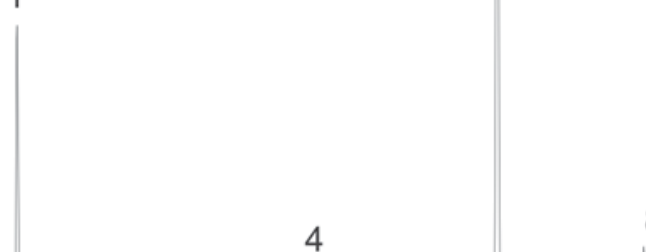

8

10 


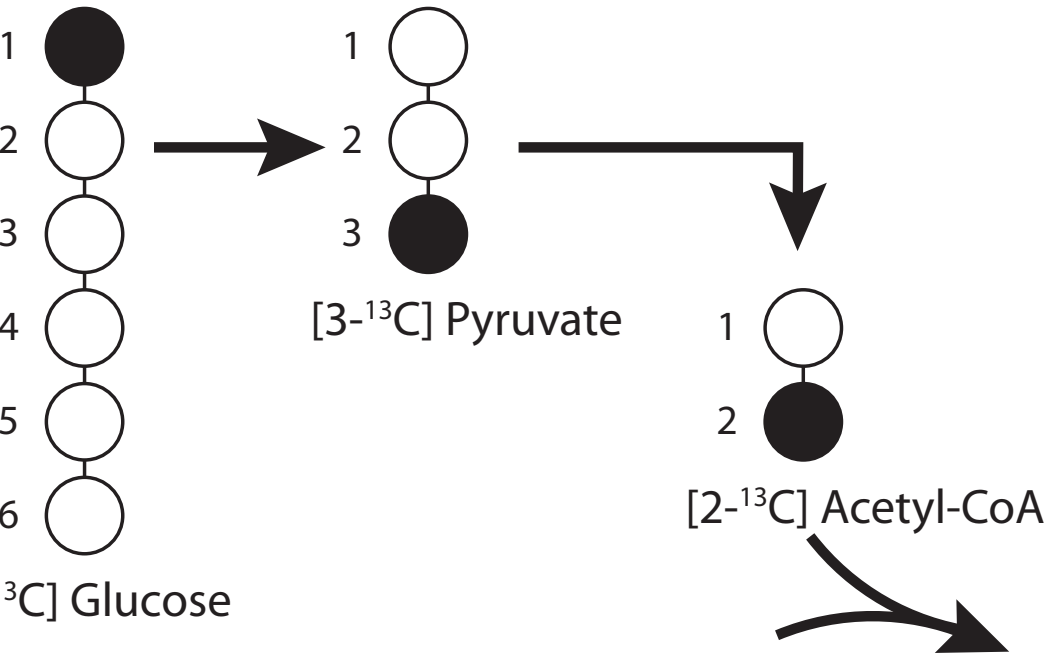

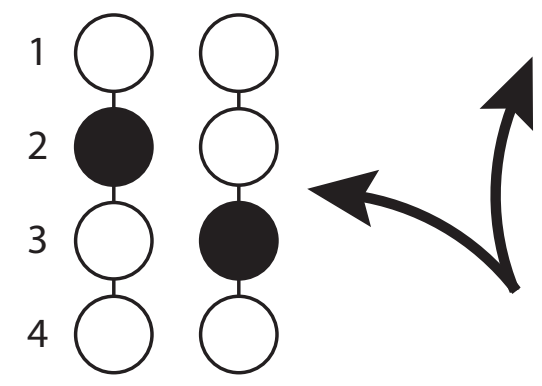

$\left[2-{ }^{13} \mathrm{C}\right]$ or $\left[3-{ }^{13} \mathrm{C}\right]$ Aspartate
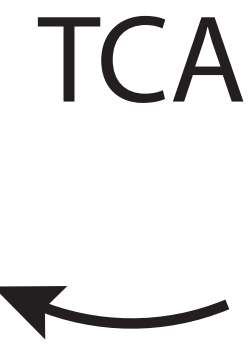

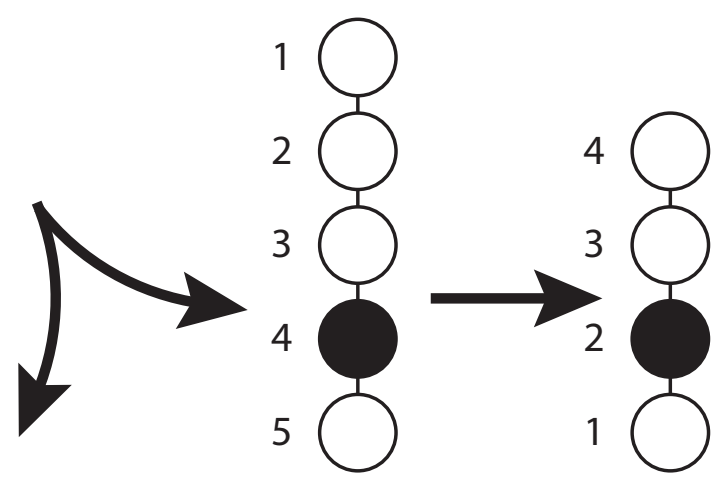

$\left[4-{ }^{13} \mathrm{C}\right] \mathrm{Glu} / \mathrm{Gln} \quad\left[2-^{13} \mathrm{C}\right] \mathrm{GABA}$

(b)

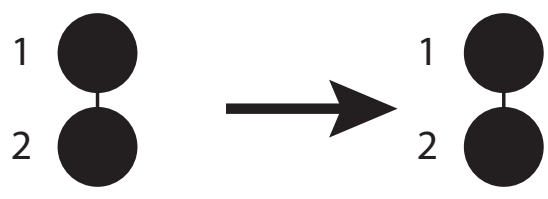

$\left[1,2-{ }^{13} \mathrm{C}\right]$ Acetate $\quad\left[1,2-{ }^{13} \mathrm{C}\right]$ Acetyl-CoA
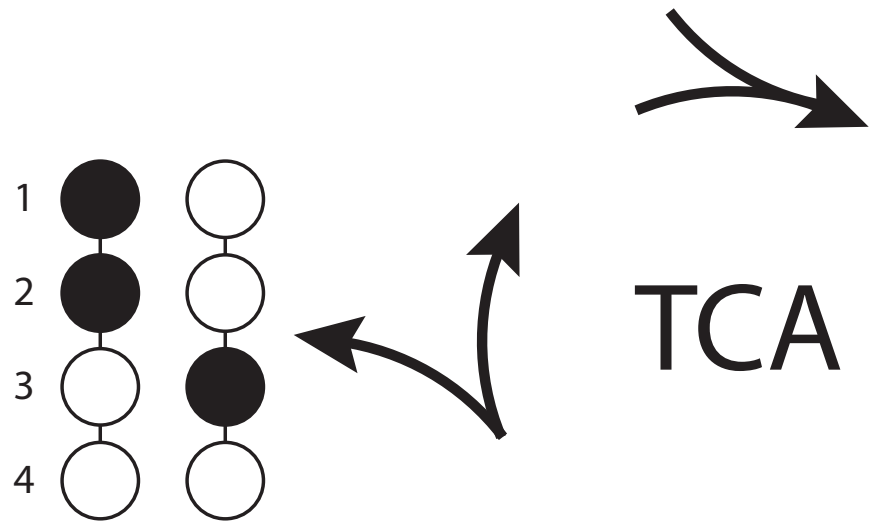

$\left[1,2-{ }^{13} \mathrm{C}\right]$ or $\left[3^{-13} \mathrm{C}\right]$ Aspartate

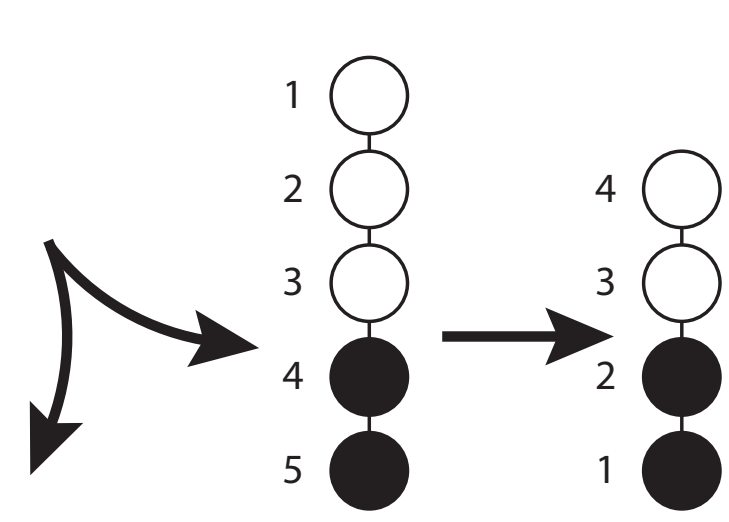

$\left[4,5-{ }^{13} \mathrm{C}\right] \mathrm{Glu} / \mathrm{Gln}\left[1,2-^{13} \mathrm{C}\right] \mathrm{GABA}$ 
(a)

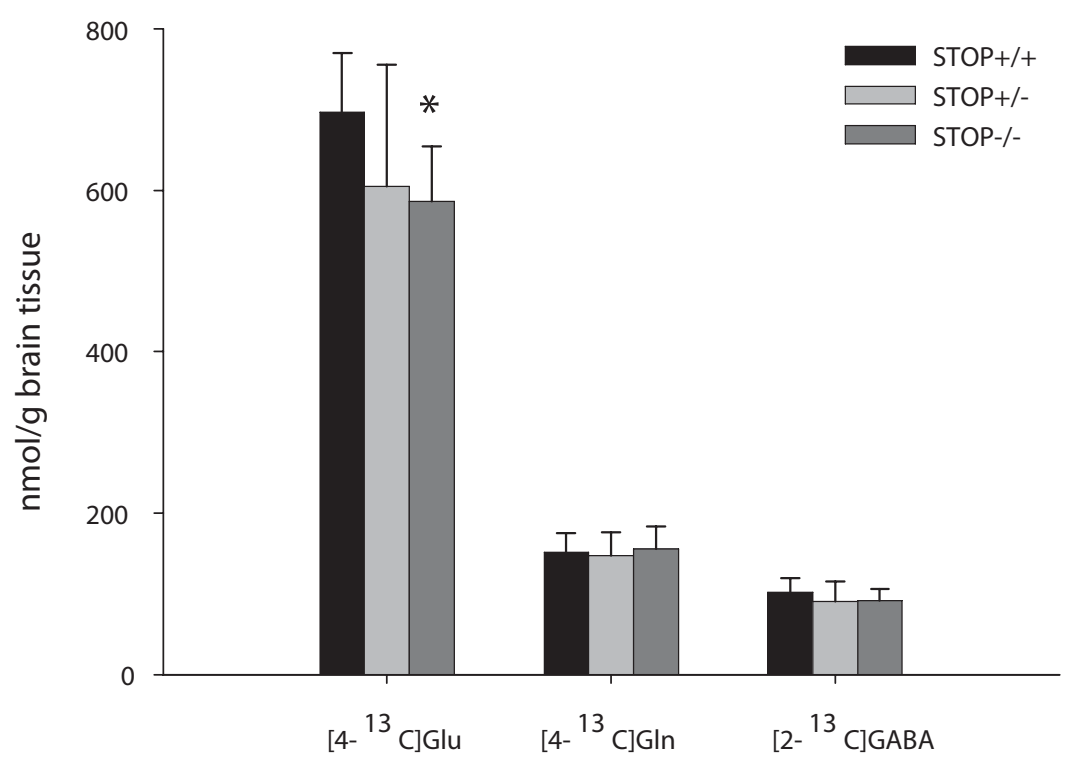

(b)

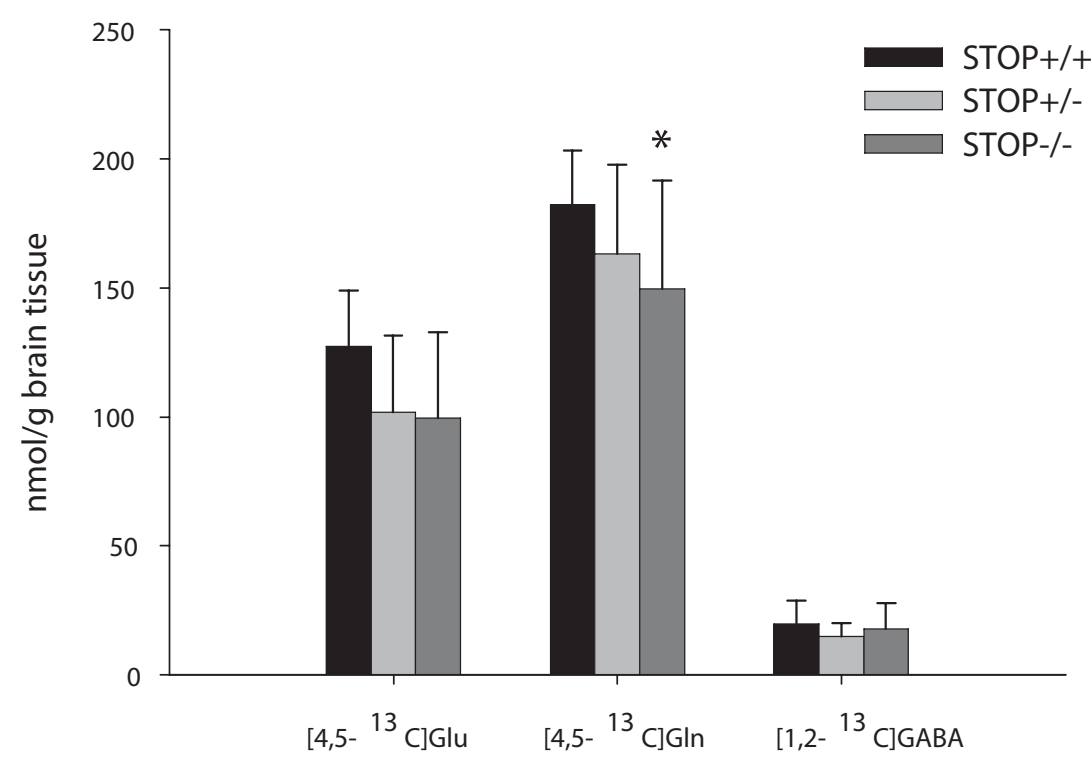




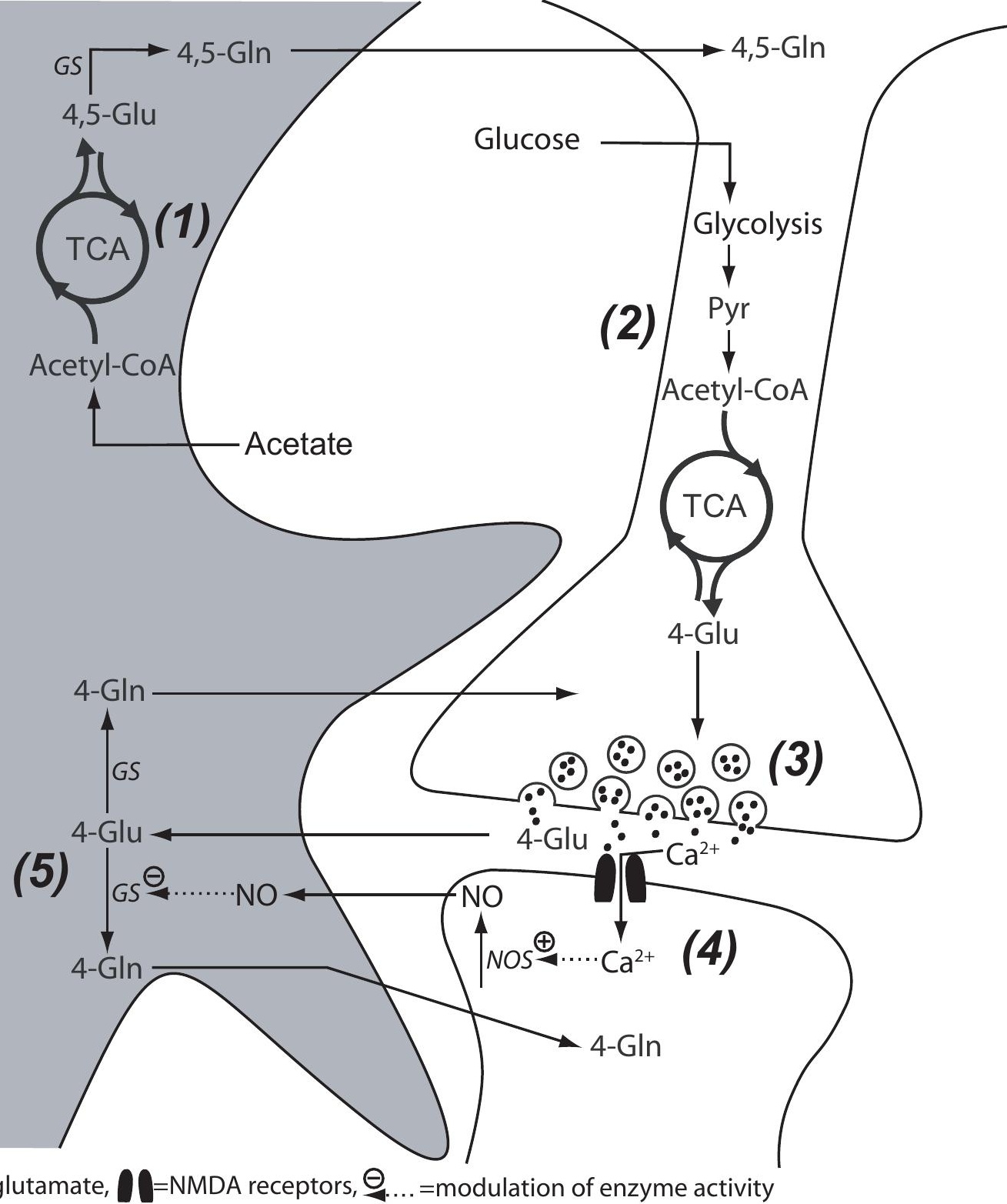

